\title{
THE RELATIONS OF TOTAL TOURISTS VISIT ON OPERATIONAL COST AT STARS HOTEL IN BULELENG DISTRICT
}

\author{
Gede Adi Yuniarta ${ }^{1}$, \\ ${ }^{1}$ Faculty of Economics, Ganesha University of Education
}

\begin{abstract}
Abstrak
This study aims to determine the relation of the number of tourist visits to the opearsional costs at Sunari Hotel. The subject of this research is Sunari Hotel which is located at Dusun Banyualit, Kalibukbuk Village, precisely on Jalan Raya Lovina Kalibukbuk Singaraja Bali, while the object of research is Relationship Number of Tourist Visits To Operational Costs at Hotel Sunari. Data collection techniques used in this study are interviews, documentation, and literature study. Analysis technique used is correlation coefficient analysis technique. The result of the research shows that the number of tourist visits to the operational cost of Sunari Hotel for the year 2016 amounted to $11.115 \%$, it means up and down the operational costs at Sunari Hotel which is influenced $11.115 \%$ the number of tourist visits and the remaining $88.885 \%$ influenced by other factors.
\end{abstract}

\section{Keywords:}

Number of tourist visits, Operational costs

\section{INTRODUCTION}

Indonesia as a developing country in its development phase is trying to build a tourism industry, as one way to achieve a balanced balance of foreign trade, because through this industry the country's foreign exchange earnings can increase. Tourism also provides a direct impetus to the progress of development, ports (sea or air), roads, transportation, sanitation or health programs and environmental sustainability all of which provide benefits and enjoyment for the community in the local environment as well as for tourists from outside visitors. Tourism also contributes to the implementation of development projects of various sectors of countries that have developed or developed its precursors, where the tourism industry is a resilience amidst other industries. The tourism sector is also a potential sector to be developed as one source of local revenue. Efforts to increase local revenue, the program of development and utilization of resources and the potential of regional tourism is expected to contribute to economic development. Widely tourism is seen as a multidimensional activity of a series of development processes.

The development of the tourism sector concerns the socio-cultural, economic and political aspects (Spillane, 2004: 14). This is in line with those stipulated in Law No. 10 of 2009 on Tourism which states that the Implementation of tourism is aimed at increasing national income, in order to improve the welfare and prosperity of the people, extending and addressing employers' and employment opportunities, encouraging regional development, introducing and utilize the objects and attractions in Indonesia and foster the love of the country and strengthen friendship between nations. The condition of Bali tourism that collapsed as a result of the tragedy of Bali bombing 1 and 2, the restaurant entrepreneurs, travel agents, and hotels in particular looking for a way out to still exist. Tourism is very big influence in economic life. The lack of a market depends on its tourism situation, as most people in Bali work in tourism such as tour guides and work in hotels and restaurants. Many of the impacts are caused by the existence of tourism, one of which is the opening of employment. With the visits of these tourists the market players above earn income that can meet their needs.

Accommodation is a very important factor, this is a "temporary home" for tourists as far or as long as the journey requires and expect comfort, good hygiene, and good service. Akomondasi in the flow of tourism industry typically shaped hotels, motels, bungalows, inns, inns, huts, homestay and others. It is an important component of tourism, where tourists can rest and eat, and there are facilities such as swimming pools, sports centers, entertainment, salons and spas.

Hotel Sunari one that provides such facilities is located at Jalan Raya Lovina, Kalibukbuk Village, Singaraja, Bali, its tranquil location close to lovina beach with the beauty of the waves and sunset is perfect for tourists who want to visit by enjoying the beach atmosphere, the hotel also has facilities 
include business center, bar, restaurant and has swimming pool, outdor as well as spacious rooms with full facilities such as Ac, private balcony, mini bar and cable tv. Guests can also enjoy massage, body treatments and hot tubs at the traditional Balines Spa and have free internet facilities in public areas.

All that is important to support the progress of tourism continues to stay smoothly, we must realize also to enforce the tourism industry, government politics directly or indirectly affect the tourist visit that is the economic situation, politics and security in the country stable is a major requirement. Sometimes due to the incompatibility of the situation of multi-ethnic Indonesian society is faced with things that lead to misunderstandings so that clashes here and there are not avoided as if across the archipelago of Indonesia "unsafe". The joint command of the nation's components and the whole community seeks to instill the understanding that a safe and peaceful situation can lead tourism to its true position as an industry in the form of invisible exports (due to various destinations of tourist destinations of tour packages and tourist services friendly, Indonesia must be able to membangaun intensive tourism industry and can compete with world tourism

\section{MATERIALS AND METHODS}

This research uses data with correlation coefficient analysis by describing in general about the cost of Sunari Hotel to be evaluated. The location of this research was conducted at Sunari Hotel and involved the variables of the number of tourist visits and operational costs at Hotel Sunari. The type of data used is quantitative data in the form of numbers and calculations, while the data source used secondary data that is the data writer can directly from Hotel Sunari. And the methods used to collect data are interviews, documentation, and literature study, so that from the formulation can be obtained the final result and can be drawn a conclusion.

The subject of this research is Hotel Sunari, while the object of this research is the Relationship Number of Tourist Visits To Operational Costs In Sunari Hotel. Types of data and data sources used in this study namely, quantitative data in the form of data numbers and calculations. In accordance with this study, the quantitative data dimgsud is the number of tourist visits and operational costs, and data sources used are secondary data that is obtained from the document collection of operational costs and the number of tourist visits.

Data collection methods used in this study is the method of interviewing is data collection by doing direct interaction / question and answer with pinpinan or parties that have relation with the necessary data about the influence of the number of tourists to the cost of operational at Sunari Hotel, the documentation is a collection technique and recording the data by collecting the evidence and information in the form of archives and letters indicated to obtain data on the number of tourist visits, malaui cashier, or cost control Hotel Sunari, and the study of the library is a way to explain the data by reading the various literatures that have kaitanya with research and as a research effort in drawing conclusions.

The data analysis used in this research is the correlation coefficient correlation by describing and describing quantitatively about the cost at Hotel Sunari to be evaluated, so that obtained one general conclusion. For the formulation of the problem used the formula according to (Husein Umar). In correlation statistics the relationship between two or more variables. Hubuangan anatara these variables when viewed in terms of direction can be divided into two kinds, namely the nature of one direction and opposite direction, hubunganya yangnyear direction is called positive correlation, whereas its opposite direction is called negative correlation. The two variables to be investigated are usually coded $\mathrm{x}$ and $\mathrm{y}$. To determine whether there is a relationship or not between the number of kunjuangan with operational costs, then the variable number of visiting in code $\mathrm{x}$, while variable operating costs in the code $\mathrm{y}$. To measure the relation of number of tourist visit with hotel operational cost based on data set used correlation coefficient formula:

\section{$\mathbf{r} \quad=\mathbf{n}\left(\sum \mathrm{xy}\right)-\left(\sum \mathrm{x} \sum \mathrm{y}\right)$ $\left.\sqrt{\left[n \sum x^{2}-\left(\sum x\right)^{2}\right]\left[n \sum y^{2}-\left(\sum y\right)^{2}\right.}\right]$}

Information:

$\mathrm{r} \quad=$ the correlation index number between the $\mathrm{x}$ variables and $\mathrm{y}$ variables.

$\sum_{\mathrm{xy}}=$ number of times between $\mathrm{x}$ variable and $\mathrm{y}$ variable.

$\sum \mathrm{x} \quad=$ number of $\mathrm{x}$ variable scores. 
$\sum \mathrm{y} \quad=$ number of $\mathrm{y}$ variables.

$\sum \times 2=$ sum of $\mathrm{x}$ squares.

$\sum_{\mathrm{y} 2} \quad=$ the sum of $\mathrm{y}$ squares.

For the number of tourists is a free variable (x), while for operational cost is the dependent variable (y). To be able to provide interpretation of the specified correlation coefficient is large or small influence, it can be guided by the provisions listed in the table as follows:

Table 1. Interpretation Guidelines Correlation Coefficient:

\begin{tabular}{ll}
\hline Coefficient Interval & Relationship Level \\
\hline $0,00-0,199$ & Very low \\
$0,20-0,399$ & Low \\
$0,40-0,599$ & Medium \\
$0,60-0,799$ & Strong \\
$0,80-1,000$ & Very strong \\
\hline
\end{tabular}

Source: Sugiyono (2002:183)

Then sought level of relationship between variable $\mathrm{x}$ and variable $\mathrm{y}$, with coefficient of determination formula. The coefficient of determination used to show how much influence between the two variables studied, then calculated the detrmination coefficient (Kd) with the assumption of other factors outside the variable considered constant / fixed (cateris paribus). The formula coefficient of determination (Kd) ie:

Information : $\quad \mathrm{Kd}=$ Coefficient of Determination

$\mathrm{R}=$ Correlation coefficient

Where if:

$\mathrm{Kd}=0$, Means the effect of variable $\mathrm{x}$ to variable $\mathrm{y}$, weak

$\mathrm{Kd}=1$, Means the effect of variable $\mathrm{x}$ to variable $\mathrm{y}$, strong

The influence of the low coefficient of determination is used guidelines put forward by Guilford cited by Supranto (2001: 227) are as follows:

Table 2. Guidance on Interpretation of Coefficient of Determination

\begin{tabular}{ll}
\hline Statement & Information \\
\hline$>4 \%$ & Very Low Effect \\
$5 \%-16 \%$ & The Influence Of Low But Sure \\
$17 \%-49 \%$ & Influence Simply Means \\
$50 \%-81 \%$ & High or Strong Influence \\
$>80 \%$ & High Influence Once \\
\hline
\end{tabular}

Source : Supranto (2001:227)

\section{RESULTS AND DISCUSSION}

From the above discussion, regardless of the history and structure of organization and authority on Sunari Hotel it can be explained that the cost incurred in January according to the number of tourist visits at the end of the year quite a lot. In February there was a decrease in the cost of about $31.6 \%$ due to the decline in the number of tourist visits. The cost of the hotel must be decreased originally in January of Rp. 316.048.205 with the number of tourist visits 1070 to Rp.215,869,032 in February with the number of tourists visit 959, then the difference in cost from January to February is Rp.100.179.182 and the number 
of tourist arrivals is reduced to 111 this means the number of influential tourists visit Back to the Folder to the operational costs incurred at Hotel Sunari. So if there is a decrease in tourist visits then the operational costs in hotels also participate reduced.

The number of tourist visits in March increased again and there was a decrease again in April and May, approaching the month of June increased the cost and number of visits from the previous month, the increase lasted until August is caused because in these months is the holiday month. Furthermore, from September to November again decrease the number of tourist arrivals until December has increased again until the end of the year holidays.

Meanwhile, to know the relation of number of tourist visit to operational cost at Sunari Hotel used calculation formula of kolerasi coefesion and to know how big influence of number of tourist visit terhahap operational cost used coefesion determination formula. By describing the formulas can be obtained results of 0.334 from the calculation coefesion kolerasinya, which means hubungsn between the number of tourist visits with operational costs issued indicate a positive direction with indicators of the relationship of both variables including low, this can be interpreted if the number of tourist visits increased then operational costs are also increasing but in the low indicator. Furthermore, the calculation of the coefficient of determination in obtaining the result of $11.115 \%$ means that the rise of the operational cost is $11.115 \%$, which is influenced by the number of tourist arrivals with low but definite effect indicator, and the remaining $88.55 \%$ is influenced by other factors. Conducting this research to know the relation of number of tourist visit to operational cost, hence problem and purpose of this research have been formulated until can be known or achieved

\section{CONCLUSIONS AND SUGGESTIONS}

Based on the results of research and discussion that has been described about the relation of the number of tourist visits to operating costs at Sunari Hotel can make conclusion that the calculation obtained results $\mathrm{r} x \mathrm{xy}=0.334, \mathrm{r} 2=11.115 \%$ then 'can be drawn the conclusion that anatara number of tourist visits to the cost- operational cost at Sunari Hotel there is a correlation that show positive keaarah, meaning that if the number of visits increased then the amount of operational costs also increase but with the indicator of a low relationship. Furthermore, how big the relationship of tourist visits with operational costs by using the formula coefesion determination obtained results $11.115 \%$ this means that the rise of the operational costs at Sunari Hotel influenced by $11.115 \%$ by the number of tourist visits with low indicator but certain and the rest in by other factors. Based on snistrations and conclusions above, then suggestions that can be given as consideration for Sunari Hotel in increasing the number of tourists visit, there are several ways that can be done in the form of bundling discounts, giving special packages on holidays, and also on the birthday hotels to increase the interest of tourists for a vacation, and Hotel Sunari is able to increase the quantity and quality of hotel services in each department in order to maintain a good image in the eyes of tourists.

\section{REFERENCE}

Maher, 1997. Akuntansi Biaya Jilid 1. Jakarta : Erlangga

Mulyadi, 1990. Akuntansi Biaya Edisi 4. Yogyakarta : BPFE.

Mulyadi, 1993. Akuntansi Biaya Edisi 5. Yogyakarta : STIE

Mulyadi,1989. Sistem Akuntansi Edisi ke 2. Yogyakarta : Sekolah Tinggi Ilmu Ekonomi YKPN. Nata, Wirawan, 2001. (Statistik Deskristif). : Keraras Emas

Pendit, Nyoman S, 2003. Ilmuu Pariwisata Cetakan Ketujuh. Jakarta: PT. Pradnyan Paramita.

Pegantar pariwisata, 2004. Sekolah Pariwisata Bali. 
Rahtoem,2014. Deskripsi Tentang Ilmu Perhotelan.(online). $\underline{\text { Http://rah- }}$ toem.blongspot.com/2014/07/deskripsi-tentang-indutstri-perhotelan.html?m=1, $\quad \underline{\text { diakses }}$ tanggal 8 Juni 2017)

Spillane, 2014. Pengartuh Sektor Pariwisata Terhadap Perttumbuthan Ekonomi

(Online)

(http://asyharnotes.blogspot.co.id/2014/pengartuh-sektor-pariwisata-terhadap.html?m=1, diakses tanggal 1 juni 2017)

Sugiono,2002. Metode Penelitian (online)

http://digilib.unpas.ac.id/files/disk1/153/jbptupaspp-gdl-rimaamelia-2607-3-bsbii.pdf (diakses tanggal 8 juni 2017)

Sujana, 2001. Metode Statistika. Bandung : PT. Tarsito Bandung.

Sulistyono, 1990. Manajemen Penyelengaraan Hotel. Bandung : CV. Alfabet

Supranto. 2001. Objek dan Metode Penelitian.(online)

(http://elib.unikom.ac.id/dowload.php?id=93833 diakses tanggal 5 juni 2017)

Supriono, 1983. Akuntasi Biaya. Yogyakarata : BPFE

Sutrisno, Hadi. 1983. Metodologi Reserch Jilid 3. Yogyakarta : ANDI Yogyakarta 